\title{
LA IMAGEN PÓSTUMA DEL CABALLERO EN LA CASTILLA BAJOMEDIEVAL: METONIMIAS DE SU CONDICIÓN
}

\section{THE POSTHUMOUS IMAGE OF THE KNIGHTS IN THE GOTHIC CASTILIAN: METONYMIES OF THEIR CONDITION}

\author{
Marta Cendón Fernández \\ Universidad de Santiago de Compostela
}

Resumo: El arte es una fuente de primer orden para apreciar la imagen que los caballeros transmitieron a la sociedad de su época, y la que de ella -en este caso el Medievo- ha llegado a nosotros. Circunscribiéndonos al mundo funerario, hemos de considerar algunos elementos que, como metonimias -representaciones del todo mediante una parte-, resumen los elementos más característicos de la condición de caballeros: así nos vamos a referir a escenas cinegéticas y alusiones a ellas, como la presencia del perro en los sepulcros; representaciones del caballo, animal del que procede su nombre, que queda recogido como un elemento fundamental en el ritual funerario; los acicates o las espuelas, indispensables para montar a caballo, y recuerdo de la unión entre caballería y nobleza; $\mathrm{y}$, por supuesto, la espada, principal distintivo de su condición como bellatores.

Palavras-chave: Caballeros. Escultura funeraria. Castilla Bajomedieval.
Abstract: Art is an important source to appreciate the image that the knights transmitted to the society of their time, and that of it - in this case the Middle Ages - has come to us. Circumscribing us to the funerary world, we have to consider some elements that, as metonymies -representations of the whole by a part-, summarize the most characteristic elements of the condition of gentlemen: thus we are going to refer to hunting scenes, and allusions to them as the presence of the dog in the tombs; representations of the horse, animal from which his name comes, which is a very important element in funerary ritual; the spurs, indispensable elements to ride a horse, and memory of the union between chivalry and nobility; and, of course, the sword, the main distinctive element of his condition as bellatores.

Keywords: Knights. Tomb Sculpture. Gothic Castilian 


\section{LOS CONCEPTOS DE NOBLEZA Y CABALLERÍA}

Los conceptos que aquí se abordan, parten de dos realidades diferentes que se acaban fusionando. Por una parte la nobleza, cuyas pautas de comportamiento presentan numerosos rasgos de continuidad con respecto a las aristocracias altomedievales en lo que se refiere a apetencias de poder y aspiraciones, para las que utilizan semejantes procedimientos $^{1}$, posee diversas definiciones según se considere desde un punto de vista social, o desde uno jurídico ${ }^{2}$. Por otra parte, la caballería, como grupo armado a caballo, que sería en origen, se destaca del resto del grupo tribal y forma parte de los más antiguos cuerpos militares $^{3}$. Ambos poseen algo en común: son grupos privilegiados dentro de su sociedad.

Los siglos centrales de la Edad Media constituyen el período fundamental en la definición del concepto de nobleza ${ }^{4}$; sin embargo su interpretación no está exenta de divergencias. Según Marc Bloch, no todo grupo dominante es nobleza, pues para merecer dicha denominación se necesitaban algunos requisitos, como un estatuto jurídico privilegiado, conseguido por vía hereditaria, que responde a ciertos códigos de reconocimiento social ${ }^{5}$; era preceptiva, pues, la adopción de los ritos y usos de la caballería ${ }^{6}$. Para Génicot, la nobleza medieval es independiente de la caballería y anterior a ella, ya que es una condición que se hereda de los antepasados (nobilibus ortus o "gentilhombre"), sin que se tenga en cuenta la riqueza o el poder 7 . Esto nos llevaría a una cuestión de fondo: ¿el noble nace o el noble se hace?. En este último caso, adquirir tal condición se debería a la demostración de ciertos valores y cualidades. Por el contrario, el principio hereditario pone el acento en la fuerza de la sangre ${ }^{8}$; esta última visión es la que

\footnotetext{
${ }^{1}$ QUINTANILLA RASO, M.C. Nobleza y caballería en la Edad Media. Madrid: Arco Libros, 1996, p. 30.

${ }^{2}$ QUINTANILLA RASO, M.C. Nobleza y caballería, p. 33.

${ }^{3}$ VALLEJO NARANJO, C. La caballería en el Arte de la Baja Edad Media. Sevilla: Universidad de Sevilla. Secretariado de Publicaciones, 2013, p. 23-24.

${ }^{4}$ Como recopilación bibliográfica sobre este tema en España, véase: SANZ CUESTA, M., RUBIO LINIERS, M.C., GARCÍA-HERNÁN, D. La nobleza en españa. Bibliografías de Historia de España (BIHES), n. 11, Madrid: Centro de Información y Documentación Científica, 2001.

${ }^{5}$ BLOCH, M. La société féodale. Paris: Albin Michel, 1968, p. 445-460.

${ }^{6}$ QUINTANILLA RASO, M.C. Nobleza y caballería, p. 31. Véase asimismo AURELL, M. La noblesse occidentale à la fin du Moyen Age: bilan historiographique et perspectives de recherche. Memoria y Civilization, n. 1, 1998, p. 97-110.

${ }^{7}$ PALLARES MÉNDEZ, M.C., PORTELA SILVA, E. Galicia en la época medieval. In : Galicia. Historia, tomo II, A Coruña: Hércules, 1991, p. 291.

${ }^{8}$ QUINTANILLA RASO, M.C. Nobleza y caballería, p. 32-33.
}

$$
61
$$


acaba triunfando al relacionarla con el concepto de linaje ${ }^{9}$, el cual se fue fraguando poco a poco. Así, según Duby, a finales del siglo IX el parentesco se organizaba horizontalmente como un grupo que reúne, a lo largo de dos o tres generaciones, a consanguíneos y parientes. En su opinión, durante el siglo $\mathrm{X}$ - cronología que varía según las regiones- este conjunto fue sustituido por otro vertical ordenado en función de la "agnatio", que los príncipes adoptaron y se propagó por mimetismo con bastante rapidez ${ }^{10}$. Según Sánchez Saus, el linaje en sentido restringido comprende tres generaciones, mientras que en sentido amplio "es una comunidad de afectos e intereses, receptáculo de un pasado familiar sin el que el hombre medieval no podía concebirse a sí mismo, y proyectar hacia el futuro de su escala de valor $y$ de sus aspiraciones" $"$. Asimismo constituye el marco por excelencia de la vida personal, incluso más allá de la muerte, y resulta un eficaz estabilizador social al forjar una mentalidad aristocrática y jerárquica. Todo ello se refuerza con la institución de los mayorazgos que concentra en los primogénitos el patrimonio señorial. De acuerdo con las disposiciones jurídicas:

Los mayorazgos son una vinculación civil perpetua, por virtud de la cual se realiza una sucesión en la posesión y disfrute de los bienes según las reglas especiales de la voluntad del testador o fundador, $y$, en su defecto, por las generales de la ley establecida para los regulares ${ }^{12}$.

En general, existen divergencias acerca del momento en que comenzaron ${ }^{13}$. Ya en Las Partidas de Alfonso $\mathrm{X}$ al heredero principal se le mejoraba en un tercio y en un quinto del patrimonio total. Pero el mayorazgo va mucho más allá, pues inmoviliza un lote de bienes y los asigna como soporte del estado nobiliario del titular ${ }^{14}$. Sus rasgos definidores quedarán marcados por la indivisibilidad, inalienabilidad, perpetuidad e imprescriptibilidad, optando por la mejor línea, dentro de ella, el mejor grado, y en este, el varón y el mayor. Es verdad que existen numerosas excepciones y hay muchos casos "irregulares": en primer lugar se consideran como beneficiarios de esta mejora a los hijos legítimos, pero también se abre la puerta a los bastardos, a veces legitimados, ante la posibilidad de que la descendencia directa

\footnotetext{
${ }^{9}$ CENDÓN FERNÁNDEZ, M. Los Sotomayor ante la muerte y su reflejo en el Arte (ss. XIV-XV). Tesis de licenciatura inédita, Santiago de Compostela, 1991.

${ }^{10}$ DUBY, G. El caballero, la mujer y el cura. Madrid: Taurus, 1982, p. 80.

${ }^{11}$ SÁNCHEZ SAUS, R. Caballería y linaje en la Sevilla medieval. Sevilla: Diputación de Sevilla, 1989, p. 39.

${ }^{12}$ MESA FERNÁNDEZ, A. Los mayorazgos españoles en la Edad Media. Hidalguía, Madrid, n. 55, 1962, p. 947.

${ }^{13}$ MESA FERNÁNDEZ, A., p. 950.

${ }^{14}$ GARCÍA ORO, J. El marco histórico de la obra. In: APONTE, V. de. Recuento de las casas antiguas del reino de Galicia. Santiago: Xunta de Galicia, 1986, p. 41.
} 
quedase truncada por razones múltiples ${ }^{15}$. De todos modos se amenaza con desheredar a los que intentasen un matrimonio impropio del linaje, o bien se casen con cristianos nuevos, pecheros, prostitutas, judíos o sarracenos ${ }^{16}$ porque, según Diego de Valera, aquellos que son engendrados en vil pecado "en ninguna manera pasa la nobleza de sus padres" ${ }^{17}$; es decir, no son auténticos bastardos, son hijos espúreos.

Como claro ejemplo de un matrimonio impropio de linaje, y lo que ello suponía, cabe recordar lo que Aponte cuenta sobre lo acontecido al noble gallego Gómez Pérez das Mariñas:

Este Gómez Pérez desque entregó terra de Faro a Fernán Pérez, ganó la casa de Mesía (a la morte de Lope Pérez), y desque se finaron sus hijos, repartió su haçienda entre sus hijas, Doña María, casada con Diego de Andrade; Doña Ginebra, con Luis de Açebedo; Doña Constança, con Lope Sánchez de Ulloa y de Moscoso. Y porque éste no era hombre para haver generaçión, partiéronse uno de otro. Y después la Doña Constança casó con Parragués a furto de su padre, el qual por esto siempre de allí adelante cubrió la cabeça con la capilla de un capuz negro asta la muerte por aqueste caso, porque Parragués havía sido su paje, y le ayudó a levantar la Proba de Párraga; más después le pesó, porque también Parragués quisiera ser primogénito de Gómez Pérez, no agradeçiendo a quien le hiçiera ${ }^{18}$.

A todo ello se suma que el prestigio de la aristocracia no descansa solo sobre el poder político o sobre la riqueza, puesto que tiene un valor preferente la consideración de una cualidad mágica ligada al alto nacimiento ${ }^{19}$, aspecto sobre la cual se suele insistir en las genealogías $^{20}$, en las que se abordan temas diversos relacionados con las familias: políticos, religiosos, de sociedad, cultura, acciones, estructuras, mentalidades ${ }^{21}$. No obstante, desde el siglo XI, por contaminación de obras de imaginación y divertimento, se produce una invención de líneas de ancestros míticos, es decir, héroes más cargados de gloria que de tierra o poder ${ }^{22}$.

\footnotetext{
${ }^{15}$ De hecho obtiene la condición de verdadero bastardo, el que es engendrado por hombre casado con mujer soltera, alcanzando la nobleza si su madre la posee. KEEN, M. La caballería. Barcelona: Ariel, 1986, p. 213. ${ }^{16}$ GARCÍA ORO, J. El marco histórico de la obra, p. 43.

${ }^{17}$ KEEN, M. La caballería, p. 213.

${ }^{18}$ APONTE, V. de. Recuento de las casas antiguas del reino de Galicia. Santiago: Xunta de Galicia, 1986, pp.158-159.

${ }_{19}$ VAUCHEZ, A. Beata stirps: sainteté et lignage en occident aux XIII et XIV siècles. In : Religion et société dans l'Occident Médiéval. Torino: Bottega Erasmo, 1980, p. 262.

${ }^{20}$ CENDÓN FERNÁNDEZ, M. De los orígenes míticos de los linajes regios y nobiliarios en la Castilla bajomedieval. In: Idées reçues à l'époque Médiévale et Moderne en Espagne. Entre appropriation et questionnement de vérités. Bordeaux: Université Bordeaux III, en prensa.

${ }^{21}$ GENICOT, L. Les généalogies. In : Typologie des sources du Moyen Agê Occidental, fasc. 15. Louvain: Turnhout, 1975, p. 1-44.

${ }^{22}$ GÉNICOT, L., p.40-43.
} 
Estas características de la nobleza se observan en el valor de unas estructuras familiares jerárquicas, con una sucesión agnaticia anclada sobre una tierra, un dominio, un castillo $^{23}$; todo ello sin olvidar diversos aspectos, muchas veces basados en el ideal, como el honor como piedra angular de transmisión en los linajes, y virtudes que Gibello ha estudiado: la fama, la generosidad, el valor, la vergüenza, el servicio y educación o la honra $^{24}$. Todos estos aspectos forman parte del concepto de nobleza que define Cadenas:

El reconocimiento, hecho por el Soberano o por la Ley, a favor de una persona, de la concurrencia en ella, en grado extraordinario y notable, de todas o alguna de las Virtudes Cardinales proyectadas al exterior en beneficio de la Patria o de la comunidad, y transmisible como virtualidad, en algunos casos, a todos sus descendientes directos" 25 .

Es decir, la nobleza se basa en la práctica de una serie de virtudes, que al restringirlas a las Cardinales permite a este autor una diferenciación con la santidad que comprendería estas junto con las Teologales.

Por su parte, el caballero fue identificado por Keen como:

Un hombre de la aristocracia y probablemente de noble linaje, que si es requerido, tiene posibilidad de proveerse de un corcel y de armas para combatir a caballo y que mediante un cierto ritual se ha convertido en lo que es, es decir que se le ha armado caballero (...) La caballería no puede separarse de la guerra, del guerrero a caballo, ni tampoco de aristocracia, porque los caballeros por lo general eran hombres de alto linaje; y desde mediados del siglo XII este término hace alusión a nociones éticas o religiosas, aunque sigue siendo una palabra difícil de definir, imprecisa en sus implicaciones ${ }^{26}$.

Esta podría considerarse una definición aplicable a los orígenes de la caballería y válida todavía para el siglo XIII ${ }^{27}$, momento en que se produce un reajuste de su significado como orden estamental. El mismo Alfonso X intentará a través de Las Partidas subrayar:

Caballería fue llamada antiguamente la compañía de los nobles hombres que fueron puestos para defender las tierras; y por eso le pusieron nombre en latín militia, que quiere tanto decir como compañías de hombres duros y fuertes y escogidos para sufrir males, trabajando y penando en pro de todos comunalmente. Y por ello hubo este nombre de cuento de mil, pues antiguamente de mil hombres escogían uno para hacerle caballero, mas en España llaman caballería no por razón que andan cabalgando en caballos, mas porque bien así como los que andan a caballo van más honradamente que en otra bestia, otrosí los que son escogidos para caballeros son más honrados que todos los otros defensores (Partida II, tit.21, ley 1).

Y en la ley 2 y 3 pone en relación la caballería con la nobleza:

\footnotetext{
${ }^{23}$ Para una visión de conjunto sobre la nobleza medieval en España, véase GERBET, M-C. Les noblesses espagnoles au Moyen Âge XI ${ }^{e}-X V^{e}$ siècle. Paris: Arman Colin, 1994. Una visión general desde el siglo V, AURELL, M. La noblesse en Occident ( $V^{e}-X V^{e}$ siècle). Paris: Armand Colin, 1996.

${ }^{24}$ GIBELLO BRAVO, V.M. La imagen de la nobleza castellana en la Baja Edad Media. Cáceres: Universidad de Extremadura, Servicio de Publicaciones, 1999.

${ }^{25}$ CADENAS Y ALLENDE, F. de. Concepto de nobleza. Hidalguía, Madrid, n. 37, 1959, p. 861-866.

${ }^{26}$ KEEN, M., p. 13-14.

${ }^{27}$ SÁNCHEZ SAUS, R. Caballería y linaje, p. 32.
}

\section{4}


Por esto sobre todas las otras cosas miraron que fuesen hombres de buen linaje, porque se guardasen de hacer cosa por la que pudiesen caer en vergüenza, y porque estos fueron escogidos de buenos lugares y algo por eso los llamaron hijosdalgo, que muestra tanto como hijos de bien. $\mathrm{Y}$ en algunos otros lugares los llamaron gentiles, y tomaron este nombre de gentileza, que muestra tanto como nobleza de bondad, porque los gentiles fueron hombres nobles y buenos, y vivieron más ordenadamente que otra gente. Y por eso los hijosdalgo deben ser escogidos, que vengan de derecho linaje de padre y de abuelo hasta en el cuarto grado, a los que llaman bisabuelos. Y esto tuvieron por bien los antiguos, porque de aquel tiempo en adelante no se pueden acordar los hombres, pero cuanto de allí en adelante más de lejos vienen de buen linaje, tanto más crecen en su honra y en su hidalguía (Partida II, tit.21, ley 2).

Hidalguía, según dijimos en la ley antes de esta, es nobleza que viene a los hombres por linaje, y por ello deben mucho guardar los que tienen derecho en ella, que no la dañen ni la mengüen, y pues que el linaje hace que la tengan los hombres así como herencia, no debe querer el hidalgo que él haya de ser de tan mala ventura que lo que en los otros se comenzó y heredaron, mengüe o se acabe en él (Partida II, tit.21, ley 3).

Por eso concluye Sánchez Saus, que en Las Partidas, la caballería es un distintivo máximo de superioridad social desde la función guerrera, pero esto se constituye "no desde los caballeros, ente histórico real e inmediato, sino desde una abstracción aristocratizante"28. En el momento en el que uno ha de comportarse conforme a lo que le corresponde por nacimiento, las relaciones de parentesco se modelan constituyendo una sociedad de herederos: el poder de los vivos se apoya en la gloria de los muertos, en la fortuna y renombre que los antepasados han legado a su descendencia ${ }^{29}$, lo cual tiene su reflejo en la literatura relacionada con las ideas caballerescas ${ }^{30}$. A lo largo de los siglos XII y XIII el cuadro nobiliario cristaliza y un reducido número de linajes hegemónicos consolida su poder frente a la realeza ${ }^{31}$. La endogamia política y estamental va a funcionar al máximo con lo que al final de la Edad Media será muy frecuente la fusión de linajes y casas.

Realmente el predominio de la oligarquía nobiliaria no se reduce a un ámbito meramente político o económico, sino que se preocupa de marcar pautas vitales, arquetipos... que habrán de afectar a la totalidad social del momento, de tal manera que en el siglo XV en España, nobleza y dignidad se identifican, e incluso como ha indicado Rucquoi en el transcurso de la segunda mitad del siglo XV florecerán tratados de armas y de nobleza que insistirán en que la nobleza es un bien, un valor supremo, que tiene su origen a la vez de

\footnotetext{
${ }^{28}$ SÁNCHEZ SAUS, R. Caballería y linaje, p. 32.

${ }^{29}$ DUBY, G. Tiempo de catedrales. Barcelona: Argot, 1983, p. 58-59.

${ }^{30}$ LIDA DE MALKIEL, M.R. La idea de la fama en la Edad Media castellana. Madrid: Fondo de Cultura Económica, 1983, p. 198.

${ }^{31}$ GARCÍA ORO, J. La nobleza gallega en la Baja Edad Media. Las casas nobles y sus relaciones estamentales. Santiago: El Eco Franciscano, 1980, p. 4.
} 
Dios y de los reyes, y que se opone a los plebeyos, oscuros y villanos ${ }^{32}$. Por ello, y dada la tendencia de los hombres a formar parte de la clase dominante, un buen número de personajes tratará de escalar las gradas de la nobleza inferior haciéndose conferir la caballería, no solo para escapar al pago de tributos, sino también para incluirse en el grupo social de los privilegiados. De hecho los reyes sabían que la promesa de armar caballeros era un estímulo eficaz, por lo que acudían a ella con frecuencia para procurarse ayuda ${ }^{33}$.

\section{LA EVOLUCIÓN DE LA NOBLEZA Y LA CABALLERÍA.}

Es preciso tener en cuenta, que el panorama no es monolítico, pues evolucionará en relación con las diferentes circunstancias políticas y socioeconómicas.

- En un principio la nobleza estaba ligada al poder, al señorío y, por tanto, al linaje, mientras que la caballería se relacionaba con el servicio individual. En la documentación el término miles aparece con carácter genérico en el siglo X, frente a quienes ostentan la autoridad que son los condes ${ }^{34}$.

- Lo que parece haber ocurrido a comienzos del siglo XIII -entre 1180 y 12201230- es la desaparición de las diferencias entre estos dos niveles de la aristocracia: una fusión rápida, un acercamiento, una reducción de las distancias que tiempo atrás había separado los castellanos (habitantes de los castillos) de los simples caballeros. Durante este período los más humildes caballeros empiezan a transformar sus residencias, a poseer escudos familiares, a adoptar las costumbres sucesorias de los castellanos. Por otra parte, el rey y los príncipes señoriales se esforzaron por conseguir el homenaje y los servicios de los caballeros, vinculándolos a ellos y apartándolos de su dependencia de los castellanos ${ }^{35}$.

- Durante la Baja Edad Media, como afirma Moxó, aparecen claramente individualizados los ricos-homes y los caballeros o hidalgos, identificados los primeros con la alta nobleza. Aunque el nacimiento determinaba la adscripción a cada grupo, existe una cierta permeabilidad. Sin embargo, la diferencia entre ricoshomes y caballeros en Castilla obedece fundamentalmente a motivos de orden económico-social o a circunstancias de índole personal - lazos vasalláticos-, pero no

\footnotetext{
${ }^{32}$ RUCQUOI, A. Des villes nobles pour le Roi. In: Realidad e imágenes del poder. España a fines de la Edad Media. Valladolid: Ámbito, 1988, p. 196.

${ }^{33}$ SUÁREZ FERNÁNDEZ, L. Los Trastámaras de Castilla y Aragón en el siglo XV. In: MENÉNDEZ PIDAL, R. Historia de España, tomo XV. Madrid: Espasa Calpe, 1964. p. 22.

${ }^{34}$ FLORI, J. Caballeros y caballería en la Edad Media. Barcelona: Paidós, 2001, p. 58.

${ }^{35}$ DUBY, G. Hombres y estructuras de la Edad Media. Madrid: Siglo XXI, 1978, p. 230-232.
} 
existía una clara barrera jurídica ${ }^{36}$. En segundo lugar habría que tener en cuenta una nobleza de Infantes y parientes reales: durante los reinados de Sancho IV (1284-1295) y Fernando IV (1295-1312) la inestabilidad en capas altas de la nobleza ${ }^{37}$ se manifiesta en la velocidad con que se suceden los titulares de estos cargos reales ${ }^{38}$. Con Alfonso XI la crisis se mitiga ${ }^{39}$.

- Es en el siglo XIV cuando va a producirse una crisis del orden nobiliario. A las vicisitudes demográficas, agravadas por la peste ${ }^{40}$, hay que sumar las económicas ${ }^{41}$, la crisis en el ámbito de las relaciones sociales, incluso en las mentalidades. Todo ello constituye una compleja realidad, que en muchas ocasiones ha sido tratada de un modo demasiado simple ${ }^{42}$, que llevó a considerar la crisis como causa de la desaparición de la "nobleza vieja"43, por su influencia en la extinción biológica de diversos linajes y el empobrecimiento experimentado por la aristocracia. A ello habría que añadir, las campañas contra los musulmanes y las contiendas civiles; en el primer caso Alfonso XI era consciente del apoyo que le prestaba la caballería popular, pues era imprescindible para la defensa de la frontera con Granada ${ }^{44}$; por ello realiza ciertas concesiones a la nobleza caballeresca, que le hiciera sentir diferente de la villana, creando la Orden de la Banda, a la que solo podría acceder

\footnotetext{
${ }^{36}$ MOXÓ, S. de. La nobleza castellana en el siglo XIV. Anuario de Estudios Medievales, n. 8, 1970-1, p. 498-500.

${ }^{37}$ Los precedentes a esta cuestión fueron abordados en RODRÍGUEZ LÓPEZ, A. Linajes nobiliarios y monarquía castellano-leonesa en la primera mitad del siglo XIII. Hispania, n.185, 1993, p. 841-859.

${ }^{38}$ GARCÍA ORO, J. El marco histórico de la obra, p. 15.

${ }^{39}$ GONZÁLEZ MÍNGUEZ. C. Las luchas por el poder en la corona de Castilla: nobleza vs. monarquía (1252-1369). Clío \& Crimen, n. 6, 2009, p. 36-51.

${ }^{40}$ LE GOFF, J. La civilisation de l'Occident Médiéval. Paris: Arthaud, 1967, p. 144.

${ }^{41}$ LADERO QUESADA, M.A. Los Trastámara y la unidad española (1369-1517). In: Historia general de España y América, tomo V. Madrid: Rialp, 1981, p. 57. Este tema ha sido abordado abundantemente en VALDEÓN BARUQUE, J.: Aspectos de la crisis castellana en la primera mitad del siglo XIV. Hispania, n. 111, 1969, p. 5-24; Reflexiones sobre la crisis bajomedieval en Castilla. En la España Medieval: IV Estudios dedicados al Profesor D. Ángel Ferrari Núñez, Madrid, vol. II., p. 1047-1060, 1984; Las crisis del siglo XIV en la Corona de Castilla. In: HIDALGO DE LA VEGA, M.J. (et alt.). Homenaje a Marcelo Vigil Pascual: la historia en el contexto de las ciencias humanas y sociales. Salamanca: Universidad de Salamanca, 1989, p. 217-235.

${ }^{42}$ Una crítica a dicha visión en QUINTANILLA RASO, M.C. Nobleza y caballería, p.57.

${ }^{43}$ Término acuñado por Moxó en su célebre artículo: De la nobleza vieja a la nobleza nueva. La transformación nobiliaria castellana en la Baja Edad Media. Cuadernos de Historia, n.3, 1969, p. 3; para él es "aquella que se formó en la etapa más dinámica de la Reconquista", mientras que para SUÁREZ FERNÁNDEZ, L. Historia de España. Los Trastámara y los Reyes Católicos, tomo 7. Madrid: Gredos, 1985, p. 48, era la constituida en el siglo XII.

${ }^{44}$ CARCELLER CERVIÑO, M.P. La nobleza caballeresca castellana en el siglo XV: realidad y representación de un grupo social. Medievalismo: Boletín de la Sociedad Española de Estudios Medievales, n.10, 2000, p.99-100. Sobre esta cuestión véase GARCIA DIAZ, I. La política caballeresca de Alfonso XI. Miscelánea Medieval Murciana, n.11, 1984, p. 119-133.
} 
una parte de la élite caballeresca ${ }^{45}$. Con Pedro I fueron múltiples las persecuciones, ejecuciones, etc., y el exilio o alejamiento del reino de algunos representantes de las viejas familias $^{46}$, que se posicionaron a favor de Enrique en la lucha entre los dos hermanos ${ }^{47}$, proceso que se invertirá tras el triunfo de Enrique. En este sentido se observan linajes castellanos que se implantan en Portugal $^{48}$, mientras otros portugueses lo hacen en Castilla ${ }^{49}$.

- Los viejos linajes serán sustituidos por la "nobleza nueva", denominada también trastamarista, porque inicia su camino a raíz de la guerra civil de 1366-69 que eleva al trono a esta dinastía. Para Ladero aquel enfrentamiento fue:

Una especie de "revolución nobiliaria" en la que comenzó a definirse la nueva posición de la aristocracia dentro del sistema político del estado estamental castellano, y a organizarse de una manera conjunta más efectiva en la defensa de sus intereses de grupo ${ }^{50}$.

Por su parte Quintanilla considera que podría hablarse de "nobleza renovada", en un sentido que implicaría un grado importante de cambio, en el que, no obstante, estarían presentes muchos elementos de continuidad ${ }^{51}$. Los nuevos linajes surgirán de la familia real o a partir de recompensas recibidas por la pequeña nobleza tras los servicios prestados a la Corona, conocidas como "mercedes enriqueñas"52. Esta

${ }^{45}$ CARCELLER CERVIÑO, M.P. La nobleza caballeresca castellana en el siglo XV, p. 100.

${ }^{46}$ MOXÓ, S de, De la nobleza vieja, pp.24-25. Id. La nobleza castellano-leonesa, pp.50-51. También lo recoge IRADIEL MURUGARREN, P. De la crisis medieval al Renacimiento (s. XIV-XV). In: Historia de España, tomo IV. Barcelona: Planeta, 1988, p. 126.

47 FERNANDES, F.R. Os exilados castelhanos no reinado de Fernando I de Portugal. En la España Medieval, n. 23, 2000, p. 101-115.

48 VALDALISO CASANOVA, C. El exilio político de los petristas en Portugal (1369-1373). Erasmo: revista de Historia Bajomedieval y Moderna, n. 1, 2014, p. 152-168. OLIVERA SERRANO, C. La Península bajo los primeros Trastámara (1350-1400). e-Humanista, n. 10, 2008, p. 1-30.

49 ORTEGA CERVIGÓN, J.I. El arraigo de los linajes portugueses en la Castilla bajomedieval: el caso de los Acuña en el obispado de Cuenca. Medievalismo: Boletín de la Sociedad Española de Estudios Medievales, n. 16, 2006, p. 73-92. OLIVERA SERRANO, C. Beatriz de Portugal. La pugna dinástica Avís-Trastámara. Santiago de Compostela: Centro de Estudios Gallegos, 2005; El exilio portugués en la Castilla de los Trastámara: cultura contractual y conflicto dinástico. In: FORONDA, F., CARRASCO MANCHADO, A.I. (coords). El contrato político en la Europa occidental. La cadena contractual en Castilla. Madrid: Casa de Velázquez, 2007, p. 323-353.

${ }^{50}$ LADERO QUESADA, M.A. Los Trastámara y la unidad española, p.57.

${ }^{51}$ QUINTANILLA RASO, M.C. El protagonismo nobiliario en la castilla bajomedieval. Una revisión historiográfíca (1984-1997). Medievalismo: Boletín de la Sociedad Española de Estudios Medievales, n.7, 1997, p. 198. La amplia revisión historiográfica se completa con ORTEGA CERVIGÓN, J.I. La nobleza peninsular en época trastámara. Principales líneas de investigación (1997-2006). eHumanista, n.10, 2008, p. 104-132.

52 IRADIEL MURUGARREN, P. De la crisis, p.126. Ciertamente, permitieron "una amplia subrogación de la autoridad real en los señoríos, que de este modo se convertían en jurisdiccionales, y también la constitución de mayorazgos(...) Los monarcas trastámara consideraron este proceso de señorialización como elemento esencial de su régimen, pues les proporcionaba una clase política que no necesitaban pagar. Las villas se 
"nobleza nueva" se divide en tres categorías: la alta nobleza, que se distingue por títulos de duque, conde o marqués, y cuenta con rentas suficientes para mantenerse; la nobleza de caballeros leales que reciben señoríos jurisdiccionales que ayudan a conservar su posición, aunque le resultan insuficientes, por lo que desempeñan cargos públicos. El tercer nivel es el formado por hidalgos y caballeros, señores rurales o propietarios urbanos ${ }^{53}$ que obtenían del rey la condición de caballeros, porque servían con caballo en la guerra y estaban exentos de impuestos; en realidad habría una diferencia fundamental entre hidalguía y caballería, pues mientras la primera se hereda la segunda se recibe ${ }^{54}$.

- Todo este panorama esbozado a partir del reinado de Enrique II continúa desarrollándose con sus sucesores, alcanzando la llamada nobleza de servicio grandes cotas de poder. No obstante, como ha indicado Carceller ${ }^{55}$, el Derecho Común actuaba en contra de los deseos de la "rancia nobleza", pues otorgaba al príncipe la prerrogativa de conceder la caballería y la nobleza como recompensa a quien le hubiera prestado un importante servicio. Mitre estudió la evolución de la nobleza durante el reinado de Enrique III $^{56}$, en un período menos convulso. En cambio Juan II y Enrique IV hicieron uso con frecuencia de este derecho para reconocer a personajes que fueron su apoyo en los turbulentos acontecimientos políticos del siglo $\mathrm{XV}$, permitiendo el ascenso de individuos de oscura procedencia a la escena política, lo que trajo consigo las protestas de la nobleza cortesana; la concesión de la nobleza y la caballería solía ir en estos casos pareja ${ }^{57}$. Casos paradigmáticos son los de don Miguel Lucas de Iranzo o don Beltrán de la Cueva $^{58}$.

- Por último se podría culminar la evolución con la situación a finales del siglo XV, enmarcada en los grandes conflictos sucesorios tras la muerte de Enrique IV. Como Quintanilla ha destacado, Isabel promovió medidas que, en uno y otro

dividieron en realengas, abadengas y señoriales según el tipo de administración que en ellas se ejerciese", SUÁREZ FERNÁNDEZ, L. Historia de España. Los Trastámara, p. 31.

${ }^{53}$ SUÁREZ FERNÁNDEZ, L. Historia de España. Los Trastámara, p. 31.

${ }^{54}$ Amén de otras consideraciones en cuanto a la realización de trabajos, como nos dice SUÁREZ FERNÁNDEZ, L., Historia de España. Los Trastámara, p. 130.

${ }^{55}$ CARCELLER CERVIÑO, M.P. La nobleza caballeresca castellana en el siglo XV, p. 100.

${ }^{56}$ MITRE FERNÁNDEZ, E. Evolución de la nobleza en Castilla bajo Enrique III (1396-1406). Valladolid: Universidad de Valladolid, 1968.

${ }^{57}$ CARCELLER CERVIÑO, M.P. La nobleza caballeresca castellana en el siglo XV, p. 100.

${ }^{58}$ CARCELLER CERVIÑO, M.P. La nobleza caballeresca castellana en el siglo XV, p. 101. 
sentido, afectaban a los miembros de la cúspide nobiliaria: la búsqueda de la paz (1478-1480), tras la guerra de sucesión, contó con importantes apoyos nobiliarios, pero también numerosas resistencias. La reina intentó establecer pactos entre monarquía y alta nobleza, tratando de frenar la oposición de algunos de los grandes linajes —Stúñiga, Pacheco, Osorio, Quiñones, Ponce de León, etc.,- - a los que privó de plazas y derechos tomados ilegalmente, al tiempo que trataba de atraer a otros concediéndoles territorios y perdonando a algunos. En las Cortes de Toledo de 1480 se refuerzan las instituciones centrales y se incorporan otros grupos sociales a la gestión del gobierno; así se aparta la alta nobleza de algunas responsabilidades políticas - Consejo Real-, siendo sustituida por otra de letrados $^{59}$. Lo mismo se llevó a cabo en el episcopado ${ }^{60}$, donde los Reyes Católicos favorecieron su pertenencia a la clase media -tras su participación en los distintos bandos que enfrentaron a diversos sectores de la nobleza a lo largo del XV-, y su cultura, pues se precisan obispos letrados ${ }^{61}$, formados en la Universidad y alejados de las $\operatorname{armas}^{62}$.

\section{LA IMAGEN PÓSTUMA DEL CABALLERO}

A fines de la Edad Media se produjo un relanzamiento del ideal caballeresco que llevó a la equiparación entre caballería y nobleza. Esto fue propiciado por varios factores: la existencia de una mentalidad militar, el sentimiento emergente de pertenencia a un linaje glorioso, y a la procura de un estilo de vida caballeresco ${ }^{63}$. Entre las características de este modo de vida estarían, según Casado: el ejercicio de ciertos cargos al servicio de los monarcas, la práctica de la hospitalidad, el disfrute de una amplia servidumbre, la construcción de suntuosas casas, la cetrería, la tenencia de armas, el lujo en los rituales

\footnotetext{
${ }^{59}$ QUINTANILLA RASO, M.C. Medievalismo: Boletín de la Sociedad Española de Estudios Medievales, n. 13-14, 2004, p.128-129.

${ }^{60}$ AZCONA, T. de. La elección y reforma del episcopado español en tiempo de los Reyes Católicos. Madrid: C.S.I.C., Instituto P. Enrique Flórez, Imprenta Escuela de Estudios Hispano-Americano, 1960, p. 201-228.

${ }^{61}$ AZCONA, T. de. La elección y reforma, p. 201-228. Ello también es recogido por GARCIA ORO, J. Cisneros y la reforma del clero español en tiempo de los Reyes Católicos. Madrid; C.S.I.C., Instituto Jerónimo Zurita, Biblioteca "Reyes Católicos", 1971.

${ }^{62}$ AZCONA, T. Reforma del episcopado y del clero de España en tiempo de los Reyes Católicos y de Carlos V (1475-1558). In: Historia de la Iglesia en España, tomo III-1 ${ }^{\circ}$ : La Iglesia en la España de los siglos XV y XVI. Madrid: B.A.C., 1980, p. 115-209; p. 157 para la nota.

${ }^{63}$ CASADO ALONSO, H. Oligarquía urbana, comercio internacional y poder real: Burgos a fines de la Edad Media. In : Realidad e imágenes del poder. España a fines de la Edad Media. Valladolid: Ámbito, 1988, p. 338.
} 
funerarios, etc. Si en un primer momento el ideal caballeresco se había desarrollado junto a las cruzadas y en el caso español con la "Reconquista", en la Baja Edad Media se ve abocado a una adaptación a la nueva situación ${ }^{64}$-aunque todavía está vivo en el caso de Granadasupliendo la literatura su transformación en la realidad, de tal manera que florece una literatura cortesana que ofrece la imagen de un caballero idealizado ${ }^{65}$.

$\mathrm{El}$ arte es una fuente de primer orden para apreciar algunos de los aspectos citados. Circunscribiéndonos al mundo funerario, hemos de considerar algunos elementos que, como metonimias -representaciones del todo mediante una parte-, representan los elementos más característicos de la condición de caballeros; así nos vamos a referir a escenas cinegéticas, y alusiones a ellas, como la presencia del perro en los sepulcros; representaciones del caballo del señor, un elemento fundamental en el ritual funerario, o, la omnipresencia de las espuelas, indispensables para montar a caballo; y, por supuesto, la espada como elemento distintivo de su condición. A ello habría que añadir la indumentaria con la que se representa a los caballeros: desde la vestidura talar a la armadura, cuestiones que hemos abordado en otras ocasiones ${ }^{66}$ y que excederían el espacio disponible en este artículo.

\subsection{Escenas cinegéticas en los conjuntos funerarios}

Como ha indicado Montoya ${ }^{67}$ la finalidad de la caza puede ser de dos tipos: utilitario (alimentación de los ejércitos que estaban en constante movimiento; abastecimiento de hogares campesinos, conventos, e incluso palacios, tanto en alimentación como vestido ${ }^{68}$; partidas de caza comunales dirigidas por los señores para evitar la acción de las alimañas ${ }^{69}$ ), y entretenimiento, o deporte ${ }^{70}$, en la que además del contacto con la naturaleza había que añadir la preparación física necesaria para llevar a cabo sus compromisos guerreros. Es lo

\footnotetext{
${ }^{64}$ TORRES FONTES, J. Don Fernando de Antequera y la romántica caballeresca. Miscelánea medieval murciana, n. 5, 1980, p. 84-120, p. 85.

${ }^{65}$ LE GOFF, J. Lo maravilloso y lo cotidiano en el Occidente medieval. Barcelona: Gedisa, 1986, p. 112.

${ }^{66}$ CENDÓN FERNÁNDEZ, M. El caballero y la fama póstuma. Algunos ejemplos de yacentes armados en la Galicia del siglo XV. In : Arquitectura e Iconografía artística militar en España y América (ss.XV-XVIII). Sevilla: Cátedra General Castaños, 1999, p. 649-666.

${ }^{67}$ MONTOYA RAMÍREZ, M.I. La caza en el medievo peninsular. Tonos: revista electrónica de estudios filológicos, n.6, 2003 [https://www.um.es/tonosdigital/znum6/portada/Cazamur.htm]. Consulta realizada el 25 de abril de 2017.

${ }^{68}$ Caza ofensiva, en PALLARES MÉNDEZ, M.C., PORTELA SILVA, E., GELABERT GONZÁLEZ, J. Caza de los señores y caza de los campesinos en Galicia (1100-1600). In : La chasse au Moyen Âge, Actes du Colloque de Nice. Nice: Les Belles Lettres, 1980, p. 287-291.

${ }^{69}$ Caza defensiva, en PALLARES MÉNDEZ, M.C., PORTELA SILVA, E., GELABERT GONZÁLEZ, J. Caza de los señores y caza de los campesinos en Galicia (1100-1600), p. 290-291.

${ }^{70}$ Caza lúdica, en PALlares MÉNDEZ, M.C., PORTEla SILVA, E., GELABERT GONZÁLEZ, J. Caza de los señores y caza de los campesinos en Galicia (1100-1600), p. 291-293.
} 
que se denomina caza villana, frente a caza noble ${ }^{71}$. En la primera estaría la captura de animales mientras en la segunda estaría la montería y la cetrería. Ciertamente, esa doble finalidad estaba determinada por el tipo de caza que en cada momento se practicaba: caza menor, caza mayor, montería o venatoria y caza con aves, volatería o cetrería. Prosiguiendo con el resumen de Montoya, la primera se refiere a las dimensiones del animal (liebre, perdiz), fue practicada principalmente por campesinos y monjes y se consideraba esencialmente una actividad económica. La segunda era denominada así por tener en cuenta las grandes dimensiones de los animales (ciervo, oso, jabalî) que son objeto de persecución, acoso y muerte; se practicaba en los terrenos agrestes de los montes, y debido a la complejidad que encierra su práctica sirvió a los reyes y señores no solo de esparcimiento, sino de adiestramiento y preparación física y moral. El tercer tipo, aunque comenzó a practicarse en la Península Ibérica en la Alta Edad Media, en los siglos posteriores se convierte en una de las actividades preferidas de la más alta aristocracia, jugando el cuerpo un papel importante al igual que los caballos, los perros y las aves ${ }^{72}$.

Núñez considera la caza como actividad educativa, la cual estaría presente en la educación de los príncipes: Fernando I ordena que sus hijos sean adiestrados en el ejercicio de las armas y de la venatoria, tan pronto como tengan edad para correr a caballo, siguiendo la moda hispánica ${ }^{73}$. Alfonso X, en Las Partidas, indica los beneficios de la caza, como actividad propia de reyes:

Mañoso debe el rey ser y sabio de otras cosas que se vuelven en gusto y en alegría para poder mejor sufrir los grandes trabajos y pesares cuando los hubiere. Y para esto, una de las cosas que hallaron los antiguos que más aprovecha es la caza, de cualquier manera que sea, pues ella ayuda mucho a menguar los pensamientos y la saña, lo que es más menester al rey que a otro hombre; y sin todo esto da salud, pues el trabajo que en ella toma, si es con mesura, hace comer y dormir bien, que es la mayor parte de la vida del hombre; y el placer que en ella recibe es otrosí gran alegría como apoderarse de las aves y de las bestias bravas, y hacerles que le obedezcan y le sirvan conduciéndole las otras a su mano. Y por esta los antiguos tuvieron que conviene mucho esto a los reyes más que a los otros hombres (Partida II, tit.5, ley 20).

\footnotetext{
${ }^{71}$ BORD, L.J., MUGG, J.P. La chasse au Moyen Âge. Paris: Gerfaut, 2008, p. 242.

${ }^{72}$ MONTOYA RAMÍREZ, M.I. La caza en el medievo peninsular.

${ }^{73}$ NÚÑEZ RODRÍGUEZ, N. Scenes de chasse dans la peinture d l'Espagne Chretienne: San Baudilio de Berlanga. In: La chasse au Moyen Âge, Actes du Colloque de Nice, Nice: Les Belles Lettres, 1980, p. 535551.
} 
En ese ambiente habría que destacar en Castilla ${ }^{74}$ el Libro de la Caza de don Juan Manuel, tratado de cetrería de ca.132575, o el Libro de la Montería de Alfonso XI (1340$1349)^{76}$, al que se añadiría a finales de siglo el Libro de la caza de las aves (1386), del canciller Pero López de Ayala ${ }^{77}$. A ellas se podrían añadir obras portuguesas como el Tratado de Alveitaria y Cetreria, traducido al portugués en 1318 por Mestre Giraldo para el rey Don Dinís ${ }^{78}$, el Livro de Falcoaria encargado por Fernando I de Portugal (1367-1384) a su halconero Pero Menino ${ }^{79}$, o el Livro da Montaria de João I ${ }^{80}$ y, en el ámbito francés, la conocidísima obra Le libre de chasse (1387-1390), de Gaston Fébus, conde de Foix y vizconde de Béarn ${ }^{81}$, entre otras.

Núñez fue pionero a la hora de abordar el tema del significado de la caza en un contexto funerario, señalando la necesidad de una doble preparación, física y moral, en los caballeros que la practican, dentro de una caza reglamentada como un rito ${ }^{82}$. Manso, por su parte, considera la existencia de una "ideología de la caza": con sus normativas, es una ocupación digna de la nobleza y de la realeza, puesto que los reyes son sus máximos defensores y promotores; requiere un esfuerzo físico que mejora la salud corporal al favorecer el sueño y el apetito; es un medio eficaz de preparación para la guerra, como

\footnotetext{
${ }^{74}$ De los libros de cetrería, con una introducción y los textos, véase el proyecto Archivo Iberoamericano de Cetrería. http://www.aic.uva.es/introduccion.html. Consulta realizada el 17 de abril de 2017.

${ }^{75}$ Edición el pdf, a cargo de FRADEJAS RUEDA, J.M., en :

http://swordshouse.galeon.com/pdf/libro_de_la\%20caza_juanmanuel.pdf. Consulta realizada el $17 \mathrm{de}$ abril de 2017.

${ }^{76}$ Edición digital y en pdf en

https://bibliotecadigital.jcyl.es/es/consulta/registro.cmd?id=16478. Consulta realizada el 17 de abril de 2017.

${ }^{77}$ Existe una edición digital en

http://www.cervantesvirtual.com/obra-visor/libro-de-la-caza-de-las-aves--0/html/fef8ab1a-82b1-11dfacc7-002185ce6064.html Consulta realizada el 17 de abril de 2017.

${ }^{78}$ Michaëlis de Vasconcelos, C. Mestre Giraldo e os seus Tratados de Alveitaria e Cetraria. Revista Lusitana, n.13, 1910. Y su edición en Mestre Giraldo e os seus Tratados de Alveitaria e Cetraria: estudo literário e contribuiçòes para o futuro diccionário etimológico das línguas románicas peninsulares, Lisboa: Impr. Nacional, 1911.

${ }^{79}$ Texto on line: http://www.aic.uva.es/clasicos/menino/menino-intro.html Consulta realizada el 17 de abril de 2017.

${ }^{80}$ Sobre él ABALO BUCETA, J.M. El Livro da Montaria de João I. Valladolid: tesis doctoral, 2008. Asimismo CONDE, J.C. Sobre la identidad del copista del manuscrito del Livro da Montaria de João I. In : PAOLINI, D. "De ninguna cosa es alegre posesión sin compañía": Estudios celestinescos y medievales en honor del profesor Joseph Thomas Snow. New York: The Hispanic Seminary of Medieval Studies, 2010, p. 97-117.

${ }^{81}$ Edición impresa con xilografías, en https://www.wdl.org/es/item/14787/. Consulta realizada el 17 de abril de 2017. Sobre esta obra véase la edición de numerosas miniaturas en Le libre de la chasse de Gaston Phébus. Paris: Musée de la Chasse et de la Nature-Bibliothèque de l'Image, 2003. Asimismo el catálogo de la exposición Gaston Fébus: Prince Soleil 1331-1391. Paris: Grandpalais, 2011.

${ }^{82}$ NÚÑEZ RODRÍGUEZ, M. La idea de inmortalidad en la escultura gallega: La imaginería funeraria del caballero, s. XIV-XV. Ourense: Diputación Provincial, 1985, p. 27-32.
} 
ejercicio de equitación y ocasión de demostrar resistencia, valor y destreza; la aventura, el placer y la emoción benefician el estado de ánimo y, la caza combate el ocio, que es ocasión de melancolía y pecado ${ }^{83}$. Como se puede observar, algunas de estas ideas ya estaban presentes en Las Partidas, y cobran un especial valor en un espacio donde el hombre busca la inmortalidad para la cual es preciso su triunfo sobre el pecado. Entre los conjuntos funerarios en los que el tema de la caza ocupa un lugar privilegiado destacan, como estudió Núñez ${ }^{84}$, varios ejemplos portugueses ${ }^{85}$, como los de dos de los hijos de don Dinís, Fernando Sánches Rodrigues (+1335? $)^{86}$-conservado en el Museo do Carmo de Lisboa-, de quien la tradición señala que falleció debido a las heridas causadas en una montería por un jabalî ${ }^{87}$, y don Pero Afonso III Conde de Barcelos (+1354), inhumado en el monasterio cisterciense de São João de Tarouca ${ }^{88}$ (lám.1). A ellos se añaden una peana sepulcral conservada en el museo de Lamego, procedente de São João de Tarouca, atribuida tradicionalmente a doña Branca de Sousa, mujer del conde de Barcelos o a su concubina Teresa Anes, algo difícil de defender, como ha señalado Vieira, dado que no es un tema que aparezca nunca en sepulcros femeninos $^{89}$; y el de Vasco Esteves de Gatuz en Estremoz ${ }^{90}$ (lám.2). Una escena de cetrería

\footnotetext{
${ }^{83}$ MANSO PORTO, C. Reflexiones sobre la caza nobiliaria en la Baja Edad Media y su proyección en Galicia. Anuario Brigantino, n.8, 1985, p. 9-22. Asimismo El mundo profano en la imaginería gótica de los conventos mendicantes gallegos: la caza. Boletín del Museo Arqueológico Nacional, n. 18, 2000, p. 231253.

${ }^{84}$ NÚÑEZ RODRÍGUEZ, M. El sepulcro de Fernán Pérez de Andrade en San Francisco de Betanzos como expresión de una individualidad y una época. Bracara Augusta, n.35, 1981, p. 397-413.

${ }^{85}$ Véase VIEIRA DA SILVA, J.C. Memória e imagem. Reflexões sobre Escultura Tumular Portuguesa (Séculos XIII e XIV). Revista de História da Arte, n.1, Lisboa, Instituto de História da Arte - Faculdade de Ciências Sociais e Humanas, 2005, p. 47-81.

${ }^{86}$ RUIZ MALDONADO, M. El sepulcro de Fernando Sanches Rodrigues y su significación en la escultura funeraria portuguesa del siglo XIV. Goya, n. 233, 1993, p. 268-273. VARELA FERNANDES, C. Escultura Tumular do Século XIV. 1. Túmulo de D. Fernão Sanches. In : Construindo a Memória. As Colecções do Museu Arqueológico do Carmo. Lisboa: Associação dos Arqueólogos Portugueses, 2005, p. 301-309 e 342343.

${ }^{87}$ Véase imagen de Vieira da Silva en http://imago.fcsh.unl.pt/upload/escultura/es_00143.jpg . Consulta realizada el 08-04-2017.

${ }^{88}$ Véase sobre él, el estudio reciente de VARELA FERNANDES, C. D. Pedro, Conde de Barcelos, e a escolha de São João de Tarouca como "Hocus" sepulcral. In: CISTER: Espaços, territórios, paisasagens. Lisboa: Instituto Portugués do Património Arquitectónico, 2000, p. 443-450.

89 "Facto de este túmulo ser decorado, em ambos os lados maiores da arca, com cenas de caçada, seria, desde $\log$, motivo mais que suficiente para não se poder dar crédito a opiniões correntes que o querem atribuir a D. Branca de Sousa, mulher do conde de Barcelos D. Pedro (no seu testamento, ele próprio afirma que sua mulher estava sepultada em S. Domingos de Santarém) ou a Teresa Anes, concubina do mesmo conde. A temática em análise é, disso não temos dúvidas, de uso exclusivamente masculino. Como tal, continua desconhecida a personagem a quem esta arca foi destinada: os brasões nas faces menores, não sendo lavrados, perderam seguramente a pintura original que permitiria identificar os esmaltes heráldicos e a respectiva linhagem". VIEIRA DA SILVA, J.C. Memória e imagen, p. 69, nota 53. Véase una buena imagen en http://www.viajaaportugal.com/category/sin-categoria/ [Consulta realizada el 08-04-2017].

${ }^{90}$ COSTA, M. A. N. Vasco Esteves de Gatuz e o seu túmulo trecentista em Estremoz. Lisboa: Academia Portuguesa da História, 1993. Hay una gran disparidad en las datas de su fallecimiento: 1363 ó 1384.
}

\section{4}


en una de las caras menores, está presente en el túmulo de Gomes Martins (en la iglesia matriz de Monsaraz), en el que también se representa una ceremonia de exequias ${ }^{91}$.

En la corona de Castilla, aludiendo a la cetrería, cabría destacar el azor posado sobre la mano que sujeta la espada en un sepulcro lígneo de caballero, de finales del siglo XIII, o principios del XIV, que, procedente de la iglesia de la Natividad de Villasandino (o de Barriuso), se halla en la actualidad en el Museo de Los Retablos en Burgos (lám.3). Por su parte el único ejemplo conservado, con escenas de montería, está en Galicia, zona muy próxima al contexto portugués, si bien Hernando ${ }^{92}$ recoge el testimonio redactado por Sandoval en 1615 que describe los sarcófagos de los Finojosa instalados en el centro del claustro de Silos: "Sobre la una sepultura están cabalgaduras y gente que las lleva; y en la otra los bueyes, y un caballero que tiraba a un javalí, del qual está asido un perro", lo cual evidencia que debieron de existir escenas dedicadas a la montería del jabalí en un contexto funerario ya a inicios del siglo XII; sin embargo desconocemos otros ejemplos. El sepulcro gallego citado, correspondiente a la década transcurrida entre 1387 y 1397, es el de Fernán Pérez de Andrade O Boo en San Francisco de Betanzos (lám.4), que no solo cuenta con escenas de montería en la peana (lám.5), sino que en la capilla mayor, lugar inicial de ubicación de su sepulcro, se disponen dos frisos con esa misma temática (láms.6-7). Ampliamente estudiado por Núñez ${ }^{93}$, Manso $^{94}$ y Erias ${ }^{95}$, quienes remiten a su vez a una amplia bibliografía, es el paradigma del caballero que cumple muchas de las premisas que antes se señalaron como características de tal: ocupa un lugar destacado junto al monarca

\footnotetext{
${ }^{91}$ Véase REIS, P.B. O túmulo de Gomes Martins Silvestre - Proposta de análise iconológica. Trabajo dado a conocer en :

https://www.academia.edu/14010079/O_t\%C3\%BAmulo_de_Gomes_Martins_Silvestre Proposta de an\%C3\%A1lise iconol\%C3\%B3gica

${ }^{92}$ HERNANDO GARRIDO, J.L. Apuntes sobre la caza en el arte medieval hispano. Codex aquilarensis: Cuadernos de investigación del Monasterio de Santa María la Real, n.19, 2003, p. 102-126; p.115, nota 37. ${ }^{93}$ NÚÑEZ RODRÍGUEZ, M. El sepulcro de Fernán Pérez de Andrade, pp.398-399; id. El discurso de la muerte: muerte épica, muerte caballeresca. Archivo español de arte, tomo 68, n. 269, 1995, p. 17-30; Id. El caballero, su panegírico y la conjuración del miedo. Semata, n. 10, 1998, p. 361-387.

94 Además de los ya citados, MANSO PORTO, C. Contribución al estudio de las representaciones de la caza del jabalí en Galicia. Iconografía de los capiteles de Santo Domingo de Pontevedra. El Museo de Pontevedra, n. 37, 1983, p. 277-289; Id. San Francisco de Betanzos. Catálogo de los temas profanos de caza y de los religiosos próximos a ellos, conservados en el interior de la iglesia. Anuario Brigantino, t. 10, 1987, p. 121-126.

${ }^{95}$ ERIAS MARTÍNEZ, A. La eterna caza del jabalí. Anuario brigantino, n. 22, 1999, p. 317-378; Id. El jabalí dios y el jabalí demonio en los sepulcros galaicoportugueses del siglo XIV. In : FRADEJAS RUEDA, J.M. La caza en la Edad Media. Tordesillas: Instituto de Estudios Iberoamericanos, 2002, p. 39-60; Id. El jabalí emblemático en los dominios de Andrade. In: ALONSO TRONCOSO, V., RODRÍGUEZ COLMENERO, A., GOY DIZ, A. (coord.) El Golfo Ártabro: fragmentos de historia litoral y patrimonio. A Coruña: Universidade da Coruña, Servizo de Publicacions, 2014, p. 359-404.
} 
Enrique II, busca el lujo en rituales funerarios, muestra el valor de la caza en relación con su condición y manifiesta su interés por la literatura como se desprende del hecho de que su capellán Fernán Martins -quien lo había calificado como "Flor de los caballeros"-, hubiese llevado a cabo una copia de la Crónica troyana de Benoît de Sainte-Maure ${ }^{96}$.

Por otra parte, la insistencia de la representación del jabalí ligado a la casa de los Andrade, en opinión de Núñez, reitera un tipo de cacería muy concreta, muy reglamentada y que casi constituye un rito, pues sería una caza civilizada y que civiliza al que la lleva a cabo $^{97}$; como indicó Gaston Phebus, "matar al jabalí, la bestia más peligrosa, con la espada es la cosa más bella y más noble" 198 . Pero no se puede olvidar que, como indicó Núñez, el sentido último de este tipo de imágenes supone el enaltecimiento de un tipo de conducta personal -el valor-, la virtus, que se afirma en la guerra y la caza justa "para obviar un combate enloquecido y enredado en una aventura que se puede volver contra quien la practica", con una visión cristianizada de la intención que debía guiar las acciones del caballero ${ }^{99}$.

En los conjuntos funerarios, excepto aquellos singulares en los que están presentes escenas cinegéticas, que abordan diversos momentos de la montería, es una constante la presencia del perro de caza acompañando al yacente, como si se tratase de una metonimia. Un solo bajo los pies del yacente lo encontramos en casi todas las imágenes de caballeros, bien echados como en el de Rodrigo Alonso de Saavedra en el convento franciscano lucense ${ }^{100}$ (lám.8), bien con la cabeza vuelta hacia el caballero, como en el yacente de Pedro López de Ayala, en la capilla de Nuestra Señora del Cabello en el monasterio de Quejana (Álava) ${ }^{101}$ (lám.9) ${ }^{102}$, donde luce collar con el escudo de su amo. Caso excepcional, como en tantos otros aspectos, lo constituye el sepulcro de Fernán Pérez de Andrade $O$ Boo en San Francisco de Betanzos ${ }^{103}$ (lám.10), en el cual, los perros ocupan todo el lateral de la yacija

\footnotetext{
${ }^{96}$ Publicada por MARTÍNEZ SALAZAR, A. (ed.) Crónica troyana: códice gallego del siglo XIV de la Biblioteca Nacional de Madrid. La Coruña: la Excma. Diputación, 1900, digitalizada en http://biblioteca.galiciana.gal/es/consulta/registro.cmd?id=7089. Asimismo el texto en LORENZO VÁZQUEZ, R. (ed.) Crónica Troiana. A Coruña: Fundación Pedro Barrié de la Maza, Conde de Fenosa, 1985.

${ }^{97}$ NÚÑ̃EZ RODRÍGUEZ, M. La idea de inmortalidad en la escultura gallega, p.29.

${ }^{98}$ NÚÑEZ RODRÍGUEZ, M. La idea de inmortalidad en la escultura gallega, p.28.

${ }^{99}$ NÚÑEZ RODRÍGUEZ, M. La idea de inmortalidad en la escultura gallega, p.31.

${ }^{100}$ NÚÑEZ RODRÍGUEZ, M. La idea de inmortalidad en la escultura gallega, p.68.

${ }^{101}$ Un completo estudio en LAHOZ, L.M. Escultura funeraria gótica en Álava. Vitoria: Diputación Foral de Álava, 1996, p. 155-186.

${ }^{102}$ Tomada de http://viajandoconarte.blogspot.com.es/2012_06_01 archive.html . Consulta realizada el 20 de marzo de 2017

${ }^{103}$ NÚÑEZ RODRÍGUEZ, M. El sepulcro de Fernán Pérez de Andrade, p. 407.
} 
-hasta siete-, teniendo en cuenta, como se ha señalado, el papel que se concede a la caza en este conjunto funerario, y en la iglesia que lo acoge. Por otro lado, y como copia de este modelo, se vuelven a encontrar en el sepulcro de Juan Freire de Andrade también en Betanzos y en el de Fernán Cao de Cordido El Viejo, en Santo Domingo de Bonaval, en Santiago de Compostela ${ }^{104}$. Asimismo, por influjo de dicho modelo, existen ejemplos en los que, en lugar de un perro a los pies, se hallarían dos; es el caso del yacente de Pedro Fernández de Andrade en Monfero ${ }^{105}$, y el de Ares Vázquez de Vaamonde en Sobrado ${ }^{106}$, ambos monasterios cistercienses de la provincia de A Coruña.

Por lo que respecta a los perros ${ }^{107}$ el principal significado que se les suele dar es el de la fidelidad, arquetipo de la lealtad y el servicio, que se corresponde con el ideal de la sociedad feudal, fundada sobre el respeto a la palabra dada y la fidelidad del vasallo ${ }^{108}$. En realidad, como Redondo ha señalado, el perro que acompaña a su dueño después de la muerte, fue un tema ya utilizado por griegos y romanos y no es ajeno a una relación con la existencia cotidiana del difunto ${ }^{109}$. Cuando acompañan al caballero, se refuerza el reflejo del tipo de vida del noble, en la que, como ya se ha indicado, la caza era una actividad muy importante. Así lo expresaba Carderera al señalar que "estos guerreros apoyan los pies sobre el espinazo de un perro, símbolo de la fidelidad, ó sea insignia y privilegio de la nobleza por el atributo de la caza"110. Núñez insiste en su valor como "emblema de la propia condición social del caballero, además de simbolizar un aspecto de la vida (la caza)"111. Es más, la relación entre el caballero y el perro llega hasta límites insospechados; así Núñez recogiendo un aspecto de la Crónica de D. Fernando, subraya el ejemplo de un noble portugués que llevó hasta tal punto su estima al perro de caza, "que os lamçava de noite consigo na cama,

${ }^{104}$ MANSO PORTO, C. Arte gótico en Galicia: Los dominicos. La Coruña: Pedro Barrié de la Maza, 2 vols., 1993; vol. 1, p. 175.

${ }^{105}$ CHAMOSO LAMAS, M. Escultura funeraria en Galicia. Orense: Instituto de estudios orensanos "Padre Feijoo", 1979, p. 460-461. Sobre los yacentes de Monfero véase VARELA CAMPOS, P. El hombre ante el Más Allá: la Muerte y la búsqueda de inmortalidad. Cuadernos de Estudios Medievales y Ciencias y Técnicas Historiográficas, Universidad de Granada, n.18-19, 1993-1994, p. 17-33.

${ }^{106}$ CHAMOSO LAMAS, M. Escultura funeraria, p. 486-487.

${ }^{107}$ CENDÓN FERNÁNDEZ, M. La presencia de animales en los conjuntos funerarios góticos en Galicia. In : XVII Ruta cicloturística del románico internacional. Pontevedra: Anduriña, 1999, p. 180-185.

${ }^{108}$ STRUBEL, A., SAULNIER, Ch. de. La poétique de la chasse au Moyen Âge. Les livres de chasse du XIVe siècle. Paris: Presses universitaires de France, 1994.

${ }^{109}$ REDONDO CANTERA, M. J. El sepulcro en España en el siglo XVI. Tipología e iconografía. Madrid: Centro Nacional de Información y Documentación del Patrimonio Histórico, 1987, p. 210.

${ }^{110}$ CARDERERA Y SOLANO, V. Reseña histórico-artística de los sepulcros nacionales desde los primeros reyes de Asturias y León hasta el reinado de los Reyes Católicos. Boletín de la Real Academia de la Historia, n.73, 1918, p. 224-258, p. 249 para la nota.

${ }^{111}$ NUÑEZ RODRIGUEZ, M. La idea de inmortalidad en la escultura gallega, p.65. 
e en meo delles"112. Por su parte Malaxecheverría presenta incluso al perro como guía del hombre hacia tierra de los difuntos ${ }^{113}$. Ara, haciéndose eco de la teoría tradicional, indica el simbolismo de la fidelidad, y señala su generalización desde el XIII, salvo en Alemania e Italia donde prefieren colocar un león ${ }^{114}$.

\subsection{El caballo: su representación en los sepulcros castellanos}

Otro de los elementos constitutivos de la caballería que está presente en algunos conjuntos funerarios, como otra metonimia de su condición, es el caballo. Presente en la sepultura guerrera desde la antigüedad, se consideraba el compañero del héroe en el último viaje al más allá ${ }^{115}$. Tradicionalmente al caballo se le reconoce como símbolo de nobleza, rapidez, libertad y belleza, asociado al poder conquistador ${ }^{116}$. Sin embargo, la connotación positiva que alcanza en la Edad Media, no era la que poseía en la Biblia, donde los caballos del Apocalipsis poseían una carga negativa. En el medievo, en cambio, adquieren esas connotaciones de nobleza y orgullo ${ }^{117}$, teniendo en cuenta que, según Morales, el simbolismo animal refleja la mentalidad medieval hacia los animales, pero también hacia los hombres, ya que se asocia hombre y animal ${ }^{118}$.

Ya en Las Partidas se indicaba la condición que debía de poseer el caballo:

Caballos y armaduras y armas son cosas que conviene mucho a los caballeros tenerlas buenas, cada una según su naturaleza, y pues que con estas han de hacer los hechos de armas que es su menester, conviene que sean tales que con ellas se puedan bien ayudar. Y entre todas aquellas cosas de que ellos han de ser sabedores, esta es la más señalada: conocer el caballo, pues por ser el caballo grande y hermoso, si fuese de malas costumbres y no fuese sabedor el caballero para conocer esto, le vendrían por ello dos males: el uno, que perdería cuanto por él diese, y el otro, que podría por él caer en peligro de muerte o de ocasión, y esto mismo le ocurriría si no fuesen las armaduras buenas y bien hechas y con razón. Y por ello, según los antiguos mostraron, para ser los caballos buenos, deben tener en sí tres cosas; la primera, ser de hermoso color; la segunda, de buenos corazones; la tercera, tener miembros convenientes que respondan a estas dos; y aun sobre todo esto, quien bien los quisiere conocer ha de mirar que vengan de buen linaje, y este es el animal del mundo que más responde a su naturaleza (Partida II, Tit.21, ley 10).

${ }^{112}$ NUÑEZ RODRÍGUEZ, M. El sepulcro de Fernán Pérez de Andrade, p.399, nota 10.

113 MALAXECHEVERRÍA RODRÍGUEZ, I. El bestiario esculpido en Navarra. Pamplona: Institución Príncipe de Viana, 1982, p. 193-201.

${ }^{114}$ ARA GIL, J.C. Escultura gótica en Valladolid y su provincia. Valladolid: Institución Cultural Simancas, Excma. Diputación Provincial de Valladolid, 1977, p. 20.

${ }^{115}$ CARDINI, F. Quell'antica festa crudele. Guerra e cultura della guerra dall'rtà feudale alla Grande Revoluzione. Milano: Il Mulino, 1988, p.17. VALLEJO NARANJO, C. La caballería en el Arte de la Baja Edad Media, p.134.

116 GASÒLIBA, E. Signos y símbolos. Guía ilustrada de su origen y significado. Madrid: Círculo de Lectores, 2008, p.54.

${ }^{117}$ MORALES MUÑIZ, D.C. El simbolismo animal en la cultura medieval. Espacio, tiempo y Forma: Serie III, Historia Medieval, n.9, 1996, p. 229-255, p. 234.

${ }^{118}$ MORALES MUÑIZ, D.C. El simbolismo animal en la cultura medieval, p. 230. 
Cuando desde la actualidad se piensa en la Edad Media, una de las imágenes más características es la del caballero, armado de pies a cabeza, montado sobre un caballo también bien equipado ${ }^{119}$. De hecho, al caballo se le considera un verdadero símbolo de identidad del caballero. Tanto para los torneos como para las batallas, se cubren con gualdrapas cuyos colores y emblemas heráldicos se convierte en distintivos del linaje ${ }^{120}$. Por su parte, en la literatura, cuando se trata de describir al caballo, no se olvida trazar un retrato del personaje, que es un reflejo del carácter del caballero ${ }^{121}$.

En el arte medieval suele estar íntimamente asociado al jinete que lo monta, y, cuando no es así, aparecen los arreos y el atelaje ${ }^{122}$, lo cual permite observar la evolución del arnés del caballo en paralelo a la del jinete ${ }^{123}$. Por cuestiones de espacio no es posible abordarlo en este lugar, pero es de gran interés la colección de pinjantes y placas de arnés medievales conservados en el Instituto Valencia de Don Juan en Madrid, de enorme valor incluso para la iconografía ${ }^{124}$.

En el contexto funerario su representación está relacionada con el ceremonial de exequias, verdadero ejemplo de expresión de la condición caballeresca. En efecto, como indicó Beaune "uno muere según su condición y es enterrado según un orden admitido por todos"125. Las exequias a través de sus representaciones en los sepulcros han sido estudiadas, especialmente, por Gómez Bárcena ${ }^{126}$, Sánchez Ameijeiras ${ }^{127}$ y Español ${ }^{128}$. En

119 PRÉVOT, B., RIBÉMONT, B. Le cheval en France au Moyen Age: sa place dans le monde médiéval; sa médecine: l'example d'un traté vétérinaire su XIV siècle, la Cirugie des chevaux. Orléans: Paradigme, 1994, p. 7.

${ }^{120}$ PRÉVOT, B., RIBÉMONT, B. Le cheval en France au Moyen Age, p.8.

${ }^{121}$ PRÉVOT, B., RIBÉMONT, B. Le cheval en France au Moyen Age, p. 255.

122 PÉREZ HIGUERA, T. Caballos y jinetes en la Edad Media: una aproximación a través de su iconografía en Al-Andalus y en los Reinos Hispánicos. In: FLÓPEZ PLATA, P. (coord.). Mil años del caballo en el arte hispánico. Madrid: Sociedad Estatal España Nuevo Milenio, 2001, p. 37-57, p. 37.

${ }^{123}$ Sobre su evolución general, especialmente en Francia, véase PRÉVOT, B., RIBÉMONT, B. Le cheval en France au Moyen Age, p.127-164.

${ }^{124}$ MARTÍN ANSÓN, M.L. La colección de Pinjantes y Placas de Arnés Medievales del Instituto Valencia de Don Juan en Madrid. Madrid: Ediciones de la Universidad Autónoma de Madrid, 2004. Por lo abordado en este artículo, véase especialmente, el pinjante, n.72, p.86, en el que se representa la caza del jabalí.

125 BEAUNE, C. Mourir noblement à la fin du Moyen Âge. In : La mort au moyen âge. Strasbourg: Association des Historiens Médiévistes de l'Enseignement Supérieur Public, 1977, p. 125.

${ }^{126}$ GÓMEZ BÁRCENA, M.J. La liturgia de los funerales y su repercusión en la escultura gótica funeraria en Castilla. In, NÚÑEZ, M. y PORTELA, E. (coords.). La idea y el sentimiento de la muerte en la Historia y en el Arte de la Edad Media. Santiago de Compostela: Servicio de Publicacións e Intercambio Científico da Universidade de Santiago de Compostela, 1988, p. 31-50.

${ }^{127}$ SÁNCHEZ AMEIJEIRAS, M.R. Un espectáculo urbano en la Castilla medieval. Semata, n. 6, 1994, p. 141-157.

${ }^{128}$ ESPAÑOL BELTRÁN, F. El "Córrer les armes". Un aparte caballeresco en las exequias medievales hispanas. Anuario de Estudios Medievales (AEM), n. 37/1, 2007, p. 867-905. 
opinión de Sánchez Ameijeiras la representación más antigua es la del sepulcro del infante don Felipe (+1274) en la iglesia de Villalcázar de Sirga (Palencia) (lám.11), si bien Español apunta que pudo tener un precedente no conservado en el sepulcro de Rodrigo González Girón (+1256), de Santa María de Benavides (Boadilla de Rioseco-Palencia) del que existe una descripción de finales del XVI ${ }^{129}$. La escena del sepulcro del infante ha sido descrita por Sánchez Ameijeiras quien indica que en lo referente al caballo hay que destacar que lleva la cola cortada en señal de luto, en su gualdrapa se dispone el cuartelado de Castilla y Suabia y lleva el escudo reversado colgando del arzón de la silla ${ }^{130}$, lo cual se conoce en los textos de la época como "a la funerala". El mismo modelo se repite en tres de los sepulcros de miembros del linaje de Téllez de Meneses en Santa María de Palazuelos (Valladolid) (lam.12) y otro del mismo linaje procedente del de Santa María de Matallana ${ }^{131}$, actualmente conservado en el Museo de Arte de Cataluña, datables en el primer cuarto del siglo XIV. La escena del caballo enlutado con el escudo "a la funerala", acompañando al cortejo fúnebre aparece también en el que Sánchez Ameijeiras ${ }^{132}$ atribuye a Gómez Ruiz Manzanedo (+1275), procedente del monasterio de Santa María de la Vega (Carrión de los Condes) (lám.13). Si bien no abundan los textos que relatan estos episodios, destaca el testamento del caballero portugués, vecino de Palencia, Alonso Martínez de Olivera (1302), en el que se señala: "Item mando que lleven mis caballos cubiertos de luto con sus escudos colgando de las sillas, pintadas en ellas las mis armas, et llevenlos de mi casa fasta la iglesia delante del mío cuerpo ansi como es costumbre en los enterramientos de los caballeros et de los altos omes en Portugal"133. Por otra parte, los textos atestiguan el acompañamiento del caballo del finado, por otros caballeros con sus caballos enlutados; así, en el Libro de la Cofradía de Santiago de Burgos ${ }^{134}$, de 1388 , se señalaba que cuando falleciese un cofrade que todos los demás "que ovieren a la sazón caballos e coberturas, que fagan encobertar los cabalos e

\footnotetext{
${ }^{129}$ ESPAÑOL BELTRÁN, F. El "Córrer les armes", p. 884, nota 66.

${ }^{130}$ SÁNCHEZ AMEIJEIRAS, M.R. Un espectáculo urbano, p. 145.

${ }^{131}$ Puede verse la imagen en http://domuspucelae.blogspot.com.es/2014/01/theatrum-sepulcros-de-lostellez-de.html. Consulta realizada el 8 de marzo de 2017.

${ }_{132}$ SÁNCHEZ AMEIJEIRAS, M.R. Un espectáculo urbano, p. 147.

${ }^{133}$ SÁNCHEZ AMEIJEIRAS, M.R. Un espectáculo urbano, p. 145.

${ }^{134}$ Publicado en LAURENCÍN, Marqués de. Libro de la cofradía de caballeros de Santiago de la Fuente fundada por los burgaleses en tiempo de D. Alfonso XI. Madrid: Tipografía de la Revista de Archivos, Bibliotecas y Museos, 1904. Obra digitalizada accesible en :

http://bibliotecadigital.jcyl.es/es/catalogo_imagenes/grupo.cmd?path=10066458. Consulta realizada el 18 de abril de 2017. Un magnífico análisis sobre las prácticas descritas en dicho libro de la Cofradía y una atinada crítica a bibliografía que trató sobre él, en MENÉNDEZ PIDAL DE NAVASCUÉS, F. Discurso inaugural: atavíos burgaleses. Emblemata, n.17, 2011, p. 19-35.
} 
traerlos por la villa con el caballo de los fiados"135. Asimismo el destino final de los caballos del fallecido era la iglesia, dentro del pago de la luctuosa; Sánchez Ameijeiras ${ }^{136}$ considera que la entrega de la cabalgadura y armas del difunto puede observarse en el sepulcro de Esteban Domingo, en la catedral de Ávila ${ }^{137}$.

\subsection{Las espuelas, "marcas de honor” de la condición caballeresca}

En Castilla, a diferencia de lo que ocurre en otras zonas de Europa, en los cortejos fúnebres no se portaban las "marcas de honor" (yelmo, manoplas, espuelas, y cota de mallas), del caballero ${ }^{138}$. Estos, que constituyen otro de los elementos propios de la condición de caballero, serán parte fundamental de la indumentaria con la que aquellos van a permanecer en la memoria. A propósito de los sepulcros de caballeros, decía Vieira da Silva:

Todos eles têm em comum estes elementos identificadores - vestem túnica e manto, têm os pés cingidos por esporas e seguram, com as duas ou apenas uma das mãos, a espada embainhada (ou, quando muito, levemente saída da bainha), disposta ao centro do corpo ou lateralmente. Quer isto dizer que a imagem da nobreza explicitada nos jacentes dos séculos XIII e XIV se expressa através de dois objectos fundamentais, ambos correspondentes às funções sociais que afinal a definem como classe e, por tal, assumindo-se como verdadeiras insígnias: o nobre (desde logo identificado pelas vestes que enverga) segura a espada que simboliza o poder de julgar, de fazer justiça, de cobrar impostos e usa as esporas que o designam como cavaleiro. Este modelo iconográfico ou, se quisermos, esta explicitação imagética tão clara encontra uma tradução notável na definição inspirada e feliz de José Mattoso: «Porque nobreza significa, antes de mais, exercício efectivo das prerrogativas senhoriais, ou pelo menos direito a exercêlas. Quer dizer, portanto, desempenho das funções que nas sociedades modernas pertencem apenas, por direito, às autoridades públicas: julgar, exigir o serviço militar e lançar taxas ou impostos» ${ }^{139}$.

Esta cita resume, perfectamente, lo que tienen en común todas las representaciones de yacentes de caballeros a lo largo del medievo: la presencia de las espuelas y la espada. Ambas se entendían también como claros elementos identificativos de su condición en textos y documentos. Así queda de manifiesto en La philosophia vulgar de Juan de Mal Lara (1568): “Assi desta manera quedó en nuestro tiempo la manera de enterrar los caballeros que los llevaban con sus andas descubiertos, vestidos

\footnotetext{
135 Tomado de SÁNCHEZ AMEIJEIRAS, M.R. Un espectáculo urbano, p. 148.

${ }^{136}$ SÁNCHEZ AMEIJEIRAS, M.R. Un espectáculo urbano, p. 153.

${ }^{137}$ SÁNCHEZ AMEIJEIRAS, M.R. Un espectáculo urbano, p.153-154. ESPAÑOL BELTRÁN, F. El "Córrer les armes", p. 886.

${ }^{138}$ SÁNCHEZ AMEIJEIRAS, M.R. Un espectáculo urbano, p. 155, que sigue a Menéndez-Pidal de Navascués.

${ }^{139}$ VIEIRA DA SILVA, J.C. Memória e imagen, p. 62.
}

\section{1}


de las armas que tuvieron y puesto el capellar de grana y calçadas las espuelas" ${ }^{140}$; o en el testamento de don Pedro Fernández de Castro de 1337 quien, a pesar de su petición de ser inhumado con hábito en Santa María de Sobrado, solicita que cuando lo enterrasen "poñan conmigo hua espada miña, guarnida de ferro e huas esporas, en señal que foy caualeyro" $" 141$. Por otro lado, también la arqueología corrobora la inclusión de espada y espuelas en el ajuar funerario ${ }^{142}$.

De hecho, y a pesar de la evolución que sufre la imagen de los yacentes en Castilla, desde la indumentaria talar, como se puede apreciar en el sepulcro de Sancho Sánchez de Rojas $^{143}$, procedente del monasterio de Vileña (lám.14), hasta las representaciones de yacentes con armadura completa - las más frecuentes a partir del enfrentamiento entre Pedro I y Enrique de Trastámara ${ }^{144}$, en todas ellas están presentes los acicates o las espuelas.

Hay que tener en cuenta la diferencia entre los acicates ${ }^{145}$ y las espuelas ${ }^{146}$ propiamente dichas. Los primeros son más antiguos y consisten en un arco metálico que encaja en el talón y se puede atar bajo el puente del pie o sobre el empeine. En el centro del arco hay una pieza, a modo de clavo, que hacia el exterior posee un pequeño clavo cónico que es lo que recibe el nombre de acicate, cuya longitud puede ir variando ${ }^{147}$. En el siglo XIII surgen las espuelas propiamente dichas, que poseen una ruedecilla; esta es una arandela punteada sujeta al extremo del vástago de la espuela, que a veces se

\footnotetext{
${ }^{140}$ MAL LARA, J. de. La philosophia vulgar. Sevilla: Casa de Hernando Díaz, 1568, h. 241v. Citado por NÚÑEZ RODRÍGUEZ, M. La idea de inmortalidad en la escultura gallega, p. 65, y MARTÍN BARBA, J.J. Guayas, lutos y exequias en el itinerario del cortejo fúnebre de Fernando el Católico. De Medio Aevo, n. 9, 2016/1, p. 23-60; p.36, nota 62.

${ }^{141}$ Documento dado el veintisiete de abril de 1337 en Celanova en PARDO DE GUEVARA Y VALDÉS, E. Los señores de Galicia. Tenentes y Condes de Lemos en la Edad Media. Tomo II, A Coruña: Fundación Barrié, p. 35-36.

142 GARCÍA ÁlVAREZ-BUSTO, A. y FERNÁNDEZ CALDERÓN, N. El caballero de las espuelas doradas. Análisis arqueológico de un enterramiento nobiliario Medieval del monasterio de Corias. GLADIUS. Estudios sobre armas antiguas, arte militar y vida cultural en oriente y occidente, n. 34, 2014, p. 135-152.

${ }^{143}$ Su identificación y estudio, en RUIZ MALDONADO, M. Escultura funeraria en Burgos: los sepulcros de los Rojas, Celada y su círculo. Boletín del Museo e Instituto "Camón Aznar", n. 61, 1991, p. 45-126, p.63-69. Actualmente se encuentra en la exposición Las Edades del Hombre, que está teniendo lugar en Cuéllar.

${ }^{144}$ BRUHN DE HOFFMEYER, A. Arms and armour in Spain II. A short survey. Cáceres: Instituto de Estudios sobre armas antiguas, 1982, p. 173-174.

${ }^{145}$ EIROA RODRÍGUEZ, J.A. Antigüedades medievales. Madrid: Real Academia de la Historia, 2006, p. 104-106.

146 GARCÍA CUADRADO, A. Las cantigas: el códice de Florencia. Murcia: Secretariado de Publicaciones, Universidad, 1993, p. 337.

${ }^{147}$ GARCÍA CUADRADO, A. Las cantigas: el códice de Florencia, p. 336.
} 
convierten en estrellas de largas puntas. Este cambio, mucho menos hiriente para el caballo, se convirtió en el que, con ligeras variantes, ha perdurado hasta la actualidad ${ }^{148}$. Las espuelas se componen pues, básicamente, de un arco o cuerpo, que es la parte curva para ajustar el talón; las piernas que son las partes que van a cada costado del pie; la rodaja, que es la rueda para espolear al caballo y el pihuelo que es el punto donde se sujetan y giran las rodajas.

En los textos presentan gran variedad, de materiales -cobre, plata, hierro-, colores: doradas, estañadas, de formas: de rodadera, de roca, de púa, de punta, planas...Solo a los miembros de las categorías superiores les estaba permitido el uso de espuelas doradas: en teoría los escuderos no gozaban de estos elementos distintivos, aunque en la vida diaria no debía de ser así, como refleja la propia legislación de la época ${ }^{149}$. Así lo vemos en las Cortes de Valladolid de 1258, cuando se prohíbe el uso de espuelas doradas a los escuderos ${ }^{150}$; o en el decimosegundo artículo de las Cortes de Sevilla de 1261, realizadas durante el reinado de Alfonso X, en el que se especificaba que:

ningún escudero non traya penna blanca nin calças, nin vista escarlata nin verde nin otro panno tinto, nin traya siella de barda nin argentada nin freno dorado nin espuelas doradas nin çapatos dorados nin sonbrero con orpel nin con argentpel nin con seda, nin coma con cavallero ${ }^{151}$.

Entre los caballeros en cuyo yacente se aprecian los acicates cabe destacar el de Fernán Pérez de Andrade $O$ Boo, al que ya nos hemos referido (lám.15). La evolución se aprecia en los dibujos que se presentan, en los que se puede ver el paso a las espuelas en el de 1340 (lám.16). Un ejemplo castellano de magníficas espuelas se observa en el sepulcro del Contador López de Saldaña en Santa Clara de Tordesillas ${ }^{152}$ (lám.17).

\subsection{La espada: cordura, fortaleza, mesura y justicia}

\footnotetext{
${ }^{148}$ GARCÍA CUADRADO, A. Las cantigas: el códice de Florencia, p.336.

149 GARCÍA ÁLVAREZ-BUSTO, A. y FERNÁNDEZ CALDERÓN, N. El caballero de las espuelas doradas, p. 149.

${ }^{150}$ GARCÍA CUADRADO, A. Las cantigas: el códice de Florencia, p. 337.

${ }^{151}$ GONZÁLEZ JIMÉNEZ, M. Cortes de Sevilla de 1261. Historia, instituciones, documentos, n. 25, 1998, p. 295-312, p. 298.

152 Sobre él véase GONZÁLEZ HERNÁNDEZ, A. Un enterramiento en la capilla de Saldaña, en el monasterio de Santa Clara de Tordesillas (Valladolid). Boletín del Seminario de Arte y Arqueología de la Universidad de Valladolid, n.58, pp.301-312, 1992. Dibujo llevado a cabo por CARDERERA Y SOLANO, V. Iconografía española: colección de retratos, estatuas, mausoleos y demás monumentos inéditos de reyes, reinas, grandes capitanes, escritores, etc. desde el siglo XI hasta el XVII / copiados de los originales por Valentín Carderera y Solano con texto biográfico y descriptivo, en español y francés por el mismo autor. Madrid: Imp. de Ramón Campuzano, 1855-1864; disponible en http://bvpb.mcu.es/es/consulta/registro.cmd?id=407400. Consulta realizada el 20 de abril de 2017.
} 
En el terreno artístico Duby señala que en el arte europeo del siglo XIV las representaciones de poder suelen coincidir con la imagen del caballero, identificado como hombre de armas ${ }^{153}$, exteriorizando el deseo de inmortalizar su posición ${ }^{154}$.

La espada $^{155}$, que aparece acompañando al caballero en su lecho funerario, consta de pomo y punta, como partes extremas, el mango o empuñadura, la cruz y el hierro. Suele cubrirse con la vaina, que posee en su parte superior el bocal y en la inferior la contera o aristol, que a veces se encuentra reforzada por una guaspa ${ }^{156}$. En la escultura funeraria suele hallarse con el talabarte sobre la vaina que se anuda desde el gavilán de la cruz a la espinga ${ }^{157}$. Era el arma más noble de un caballero, distintivo de su estamento $^{158}$, dado su importante papel en la ceremonia de armar caballeros; Bruhn de Hoffmeyer señala que aunque la lanza era más efectiva, la espada era considerada la más distinguida, noble e importante ${ }^{159}$. Según Las Partidas, la espada es resumen de virtudes: cordura, fortaleza, mesura y justicia, en coincidencia con las cuatro partes de que se compone: "el arrias, el mango, la mançana y el fierro"160.

Bondades son llamadas las buenas costumbres que los hombres tienen naturalmente en sí, a las que llaman en latín virtudes; y entre todas son cuatro las mayores; así como cordura y fortaleza y mesura y justicia. Y comoquiera que todo hombre que tenga voluntad de ser bueno debe esforzarse por tenerlas, tanto los oradores que dijimos, como los otros que han de gobernar las tierras por sus labores y por sus trabajos, con todo esto no hay ninguno a quien convenga más que a los defensores, porque ellos han de defender la iglesia y los reyes y a todos los otros, y la cordura les hará que lo sepan hacer a su provecho y sin su daño; y la fortaleza, que estén firmes en lo que hicieren y que no sean cambiadizos, y la mesura, que obren en las cosas como deben y no pasen a más, y la justicia, que la hagan derechamente. Y comoquiera que estas sean en muchas maneras, sin embargo todas tornan en dos: las unas,

153 "Les représentations du pouvoir ne se séparaient pas de l'image de l'homme d'armes, c'est-à-dire du cavalier. Le seigneur, celui qui tient en mains le pouvoir de commande et de punir, est d'abord un chef de guerre ". DUBY, G. Fondements d'un nouvel humanisme 1280-1440. Genève: Skira, 1966, p.179.

${ }^{154}$ Algunos aspectos han sido apuntados en CENDÓN FERNÁNDEZ, M. La memoria pétrea en la Castilla Bajomedieval: reyes y caballeros. Cuadernos del CEMYR, n. 24, 2016, La Laguna (Tenerife), p. 145-173. ${ }_{155}$ Numerosos ejemplos de espadas en el arte y en restos arqueológicos, en BRUHN DE HOFFMEYER, A. Arms and armour in Spain II, p. 31-74 y 188-195.

${ }^{156}$ RIQUER, M. L'árnès del cavaller. Armes i armadures catalanes medievals. Barcelona: Ariel, 1968, p. 145150 y $232-235$.

157 NUÑEZ RODRIGUEZ, M. La idea de inmortalidad en la escultura gallega, p. 71.

${ }^{158}$ Tal como recoge Palacios Martín, debido al simbolismo político de la espada, debe ponerse en juego en cualquier contrato vasallático que afecte a la soberanía de alguna de las partes; así, el acto de entrega de la espada, y el acto de ceñirla a la cintura poseerán significados específicos en función de quién lo entregue, si está sobre el altar, si el propio caballero la recoge ("autoinvestidura"), etc. PALACIOS MARTÍN, B. Investidura de armas de los reyes españoles en los siglos XII y XIII. In: Gladius. I Simposio Nacional sobre "Las armas en la Historia". Cáceres: Universidad de Extremadura, 1988, p. 153-192.

159 BRUHN DE HOFFMEYER, A. Las armas en la Historia de la Reconquista. In: Gladius. I Simposio Nacional sobre "Las armas en la Historia". Cáceres: Universidad de Extremadura, 1988, p. 41.

${ }^{160}$ MARTÍNEZ MARTÍNEZ, J.G. La significación del término "armas", los modismos lingüístico-jurídicos y su valoración en la estética medieval. In: Gladius. I Simposio Nacional sobre "Las armas en la Historia". Cáceres: Universidad de Extremadura, 1988, p. 109. 
para defender el cuerpo que son dichas armaduras; y las otras, armas, que son para herir. Tuvieron por bien los antiguos hacer una en que se mostrasen todas estas cosas por semejanza, y esta fue la espada, pues bien así como las armas que el hombre viste para defenderse muestran cordura, que es virtud que le guarda de todos los males que le podrían venir por su culpa, otrosí muestra eso mismo el mango de la espada que el hombre tiene encerrado en su puño, pues cuanto así la tuviere, en su poder es de alzarla o de bajarla, o de herir con ella o de dejarla. Y otrosí como en las armas que el defensor sitúa ante sí para defenderse muestran fortaleza, que es virtud que hace al hombre estar firme a los peligros que le vienen, así en la manzana es toda la fortaleza de la espada, pues en ella se sufre el mango, y el arriaz y el hierro, pues bien, así como las armaduras que viste y las armas con que hiere, y son así como la virtud de la mesura entre las cosas que se hacen de más o de menos de lo que deben, bien a esa semejanza es puesto el arriaz entre el mango y el hierro de ella; y bien otrosí como las armas que el hombre tiene en las manos enderezadas para herir con ellas allí donde conviene, muestran justicia que tiene en sí derecho e igualdad, otrosí lo muestra el hierro de la espada, que es derecho y agudo y taja igualmente de ambas partes (Part.II, Tit.22, Ley 4).

Por otro lado se la considera símbolo cristiano, ya que por su forma evocaba la cruz, pero además en la epístola a los Efesios se dice: "Tomad también, el yelmo de la salvación y la espada del Espíritu, que es la Palabra de Dios; siempre en oración y súplica, orando en toda ocasión en el Espíritu, velado juntos con perseverancia e intercediendo por todos los santos" (Ef. 5,11-19) ${ }^{161}$.

Por otra parte, D. Juan Manuel en su Libro de los Estados, dice: "la espada significa tres cosas: la primera fortaleza, porque es de fierro; la segunda, justicia, porque corta de ambas las partes; la tercera, la cruz"162.

Ese significado que redunda en la idea del caballero como miles Christi, se desprende también de las palabras de Llull, quien afirmaba:

Al caballero se le da la espada, que está hecha a semejanza de la cruz, para significar que así como Nuestro Señor Jesucristo venció en la cruz a la muerte en la que habíamos caído por el pecado de nuestro padre Adán, así el caballero debe vencer y destruir a los enemigos de la cruz con la espada. Y como la espada tiene doble filo, y la caballería está para mantener la justicia, y la justicia es dar a cada uno su derecho, por eso la espada del caballero significa que el caballero debe mantener con la espada la caballería y la justicia ${ }^{163}$.

Además de símbolo cristiano, lo ha sido del hombre libre y, en ciertos países paganos, tuvo su propio culto ${ }^{164}$.

En la escultura funeraria de caballeros se puede observar la espada, con el talabarte, sujeta con una sola mano, como en sepulcro tantas veces indicado, de Fernán

\footnotetext{
${ }^{161}$ Edición utilizada: Biblia de Jerusalén (Ubieta, J.A. ed.). Bilbao: Desclée de Brower, 1976.

${ }^{162}$ BRUHN DE HOFFMEYER, A. Las armas en la Historia de la Reconquista, p. 41.

${ }^{163}$ LLULL, R. Libro de la orden de caballería..., texto recogido en la selección realizada por VENTURA CRESPO, C. Los caballeros medievales. Cuadernos Historia 16, n. 115, 1985, p. V.

${ }^{164}$ BRUHN DE HOFFMEYER, A Las armas en la Historia de la Reconquista, p. 41.
} 
Pérez de Andrade $O$ Boo (lám.18), quien la lleva en la izquierda, o con ambas, sobre todo hacia el final del Medievo, como en el sepulcro de don Álvaro de Luna, en la capilla de su nombre en la catedral de Toledo (lám.19).

\section{CONCLUSIONES}

A la hora de valorar las imágenes póstumas de los caballeros podemos concluir que existen una serie de elementos que hemos denominado metonimias, pues reflejan el todo de la condición de caballero, a través de una parte. Así, una de las actividades propias del caballero, no solo como entretenimiento sino también como práctica para la guerra y lucha contra el pecado que puede derivar de la ociosidad, es la caza. Si bien la cetrería se acaba convirtiendo en la actividad más aristocrática, en los conjuntos funerarios se refleja más la montería, especialmente la caza del jabalí. Tras el análisis de la escultura conservada en Castilla, se puede concluir que solo la hemos hallado en Galicia y, con mayor abundancia en Portugal, siendo el influjo del sur el que llegaría al norte. Por otra parte, si bien las escenas cinegéticas no abundan, sí es casi omnipresente el lebrel, el perro de caza, fiel compañero del noble, bajo cuyo lomo reposan en su mayor parte los pies de los yacentes; hay tal simbiosis entre el perro y su dueño, que llegan a representarse los emblemas heráldicos del señor, en el collar que lleva el animal. Una profusión heráldica que hace hincapié en el linaje, en principio privativo de la nobleza, que acaba transfiriéndose a la caballería.

En segundo lugar, dado que de caballeros se trata, existe otro animal cuya posesión era imprescindible para adquirir tal condición: el caballo. En los conjuntos funerarios, su presencia solo se ha encontrado en Castilla en algunos ejemplos de finales del siglo XIII y comienzos del XIV, en los que se representa el ceremonial de exequias. En ellos el caballo lleva su gualdrapa decorada con los emblemas heráldicos del linaje; de nuevo hay una identificación entre el animal y su montura, e incluso en Las Partidas se señala que un buen caballo ha de proceder de un buen linaje, pues es el animal que más responde a su propia naturaleza. Caballo y caballero, se han de comportar conforme a su condición, aquella que conviene a su origen. Y, por ello, directamente vinculados al caballo están los acicates y espuelas, que permiten que responda a la guía del caballero, que es quien ha de dominar al animal, como el hombre al mal. 
Por último, y como miles Christi, la espada sintetiza las virtudes de la cordura, fortaleza, mesura y justicia, las que un buen caballero cristiano ha de practicar para que su memoria en la tierra perdure, a la vez que consiga alcanzar la gloria celestial, anhelo que resulta fundamental puesto que hemos llevado a cabo un análisis de estos elementos en un contexto funerario. En el lugar de reposo definitivo, es importante remarcar las actividades que han permitido que la imagen póstuma del caballero se identifique con la del buen cristiano, que sirva como ejemplo a aquellos que lo contemplen, al tiempo que recuerden que están ante un hombre de armas, que combatió a los enemigos de la fe y defendió con esfuerzo, honra y poderío. 